\title{
Perikinetics and sludge study for the decontamination of petroleum produced water (PW) using novel mucuna seed extract
}

\author{
Matthew Menkiti ${ }^{1,2} \cdot$ Ifechukwu Ezemagu $^{2} \cdot$ Bernard Okolo $^{3}$
}

Received: 21 June 2015/Published online: 8 April 2016

(c) The Author(s) 2016. This article is published with open access at Springerlink.com

\begin{abstract}
In this study, Mucuna flagellipes seed extract was applied in the coagulation-flocculation of produced water (PW). Process parameters such as $\mathrm{pH}$, dosage, and settling time were investigated. Process kinetics was also studied. Instrumental characterization of mucuna seed (MS), mucuna seed coagulant (MSC), and post effluent treatment settled sludge (PTSS) were carried out. The optimum decontamination efficiency of $95 \%$ was obtained at $1 \mathrm{~g} / \mathrm{L}$ MSC dosage, $\mathrm{PW} \mathrm{pH}$ of 2 , and rate constant of $0.0001(\mathrm{~L} / \mathrm{g} / \mathrm{s})$. Characterization results indicated that MS, MSC, and PTSS were of network structure, primitive lattice, and thermally stable. It could be concluded that MSC would be potential biomass for the treatment of produced water under the experimental conditions.
\end{abstract}

Keywords Mucuna seed · Produced water · Coagulationflocculation · Sludge $\cdot$ Perikinetics

\section{Abbreviations \\ $K_{m} \quad$ Menkonu coagulation-flocculation rate constant \\ $K \quad$ Coagulation-flocculation reaction rate constant \\ $K_{\mathrm{R}} \quad$ von Smoluchowski coagulation constant \\ $\beta_{\mathrm{BR}} \quad$ Collision factor for Brownian transport}

Matthew Menkiti

matthew.menkiti@ttu.edu; cmenkiti@yahoo.com

1 Water Resources Center, Department of Civil and Environmental Engineering, Texas Tech University, Lubbock, TX, USA

2 Department of Chemical Engineering, Nnamdi Azikiwe University, Awka, Nigeria

3 Department of Chemical Engineering, Michael Okpara University of Agriculture, Umudike, Nigeria

Edited by Xiu-Qin Zhu

$\begin{array}{ll}\varepsilon_{p} & \text { Collision efficiency } \\ \tau_{1 / 2} & \text { Coagulation period/Half life } \\ E(\%) & \text { Coagulation-flocculation efficiency } \\ R^{2} & \text { Coefficient of determination } \\ \alpha & \text { Coagulation-flocculation reaction order } \\ -r & \text { Coagulation-flocculation reaction rate } \\ \text { MS } & \text { Mucuna seed } \\ \text { MSC } & \text { Mucuna seed coagulant } \\ \text { PTSS } & \text { Post treated settled sludge } \\ \text { PW } & \text { Produced water } \\ N_{0} & \text { Concentration of turbidity particles at time } t=0 \\ N_{\mathrm{t}} & \text { Concentration of turbidity particles at time, } t\end{array}$

\section{Introduction}

The production of oil and gas is accompanied by significant production of water, commonly known as "produced water". Although there is no report of environmental disaster of high magnitude associated with produced water disposal in Niger Delta region of Nigeria, it is nevertheless known that much of this waste fluid is discharged into the environment or re-injected into the wells (Ezemagu 2015).

Produced water (PW), highly turbid in nature, is generated during first stage of petroleum exploitation and/or as associated residual fluid during petroleum storage. Several physical and chemical factors affect the characteristics of produced water. These factors include, but are not limited to, humic acids content, suspended/dissolved organic and inorganic substances, $\mathrm{pH}$, and temperature (Frost et al. 1998; Wang et al. 2014; Ezechi and Isa 2014).

Over the years, there has been increasing concerns for the environmental protection of aquatic systems receiving 
inadequately treated PW. In order to address these concerns, different treatment techniques have been employed. They include, but are not limited to, adsorption, microfiltration, photo-catalysis, ion exchange, reverse osmosis, oxidation, coagulation-flocculation and neutralization, dissolved air precipitation, biological degradation, nanofiltration, and ultra-filtration (Shubo et al. 2002; Jerry et al. 2011; Colberg et al. 2012; Bouaziz et al. 2014; Huang et al. 2014; Ezemagu 2015).

Among these technologies, coagulation-flocculation presents a superior viable primary treatment option for the PW. The advantages of coagulation-flocculation over other technologies are: (1) easy on-site implementation, (2) high treatment efficiency, (3) simplicity, and (4) low installation and operating costs (Karthik et al. 2008). Coagulation has always been the core effluent treatment process for removal of colloidal and organic/inorganic materials, which could cause color and turbidity (Choi et al. 2008; Ugurlu et al. 2008; Zheng et al. 2009; Wei et al. 2009; Menkiti and Onukwuli 2012; Okolo et al. 2014).

Coagulation entails addition of coagulant to water in order to neutralize the charges on the colloidal particles, thus eliminating the repulsive forces that keep the particles apart, so that the particles come close enough to stick together. The continuous multiple build-up of the sticking particles into visible settleable flocs is known as flocculation (Huang and Chen 1996; Tatsi et al. 2003).

The performance of the coagulation-flocculation process is largely affected by the coagulant type, raw effluent quality, temperature, $\mathrm{pH}$, chemical and effluent's bacteriological characteristics etc. (Jin 2005; Menkiti et al. 2009). Chemical coagulants such as ferric chloride, calcium hydroxide, alum, ferric sulfate, ferrous sulfate, polyaluminium chloride, and lime (Amokrane et al. 1997; Graham et al. 2008; Yang et al. 2010; De Godos et al. 2011; Imran et al. 2012) have been widely used in removing a wide range of particles from wastewater. Nevertheless, these chemical coagulants have disadvantages, which include large volume of sludge resulting in huge disposal cost, not being effective in low-temperature water, and high procurement cost. Furthermore, aluminum-based coagulants are associated with Alzheimer disease in humans (Moraes 2004; Chen et al. 2010; Zhu et al. 2011).

Because of these inherent disadvantages of the chemical coagulants, search for alternative coagulants becomes imperative. Natural coagulants have attracted more attention due to their eco-friendliness. Natural coagulants are considered safe for human health, because they are biodegradable, natural, nontoxic, and renewable (Zhao et al. 2012; Rajab et al. 2013).These natural coagulants of plant origin include, but are not limited to, Moringa oleifera, Maize, Nirmali (Strychnos potatorum) seed, Plantago psyllium, Plantago ovata, Hibiscus esculentus seed pods,
Chestnut, Jatropha curcas seeds (Sen and Bulusu 1962; Tripathi et al. 1976; Raghuwanshi et al. 2002; Oluwalana et al. 2004; Mei Fong et al. 2014; Sciban et al. 2009). In this current work, extract from mucuna seed (MS), provided the focus for this study.

MS has been considered for use as a coagulant because it is biodegradable, nontoxic, and safe to human health. It also contains highly soluble proteins (Menkiti et al. 2010; Ugonabo et al. 2012; Ezemagu 2015). The application of either natural or mineral coagulants is associated with generation of sludge. The sludge generated during biocoagulation has not yet been studied; a gap this work is attempting to close. An insight into the basic characteristics of the PTSS could provide vital information for possible wide application of the sludge. It could also give ideas on the treatment and disposal options available for PTSS. This study also extended into how process parameters would influence the effectiveness of mucuna seed coagulant (MSC) in the decontamination of PW, in addition to the study of the process kinetics.

\section{Materials and methods}

\subsection{Material preparation and characterization}

\subsubsection{Produced water $(P W)$}

The produced water was collected from a petroleum refinery located in Port Harcourt, Nigeria. The collected sample was stored and characterized on the bases of standard procedure (APHA 1999). The Chemical Oxygen Demand was determined by following the methodology (specific to high salt containing liquid waste) as described by APHA (1999). In accordance with the procedure, the digestion mixture was prepared by adding $\mathrm{K}_{2} \mathrm{Cr}_{2} \mathrm{O}_{7}, 3 \mathrm{~g}$ (which was previously dried at $103{ }^{\circ} \mathrm{C}$ for $2 \mathrm{~h}$ ), to concentrated (18.4 M) $\mathrm{H}_{2} \mathrm{SO}_{4}, 167 \mathrm{~mL}$ and $\mathrm{HgSO}_{4}, 33 \mathrm{~g}$, and made up to $500 \mathrm{~mL}$ with distilled water. The mixture was cooled to room temperature before it was diluted to $1000 \mathrm{~mL}$. The sulfuric acid reagent $(2.5 \%$, w/v) was prepared by dissolving $\mathrm{Ag}_{2} \mathrm{SO}_{4}$ in $\mathrm{H}_{2} \mathrm{SO}_{4}$. The sampling of wastewater and digestion mixture of the sample was carried out in accordance with methodology described under the analysis of water and wastewater in the literature (APHA 1999).

\subsubsection{Mucuna seed (MS)}

The MS sample was bought from Eke-Aku market, IgboEtiti, Enugu State, Nigeria. Distilled water was used to thoroughly wash the samples of MS, which was then sun dried for 10 days. The samples were processed to MSC 
based on the modified procedure reported by Sutherland (2005). In this procedure, $100 \mathrm{~g}$ of sieved powdered MS was soaked in ethanol and the soaked mixture was continuously stirred using a magnetic stirrer for $2 \mathrm{~h} 30 \mathrm{~min}$. Next, the mixture was filtered using Whatman filter paper no 3 . The residue obtained after the filtration was transferred into a beaker containing 1:25 w/v mixture of complex salts $\left(0.7 \mathrm{~g} / \mathrm{L} \mathrm{CaCl}_{2}, 4 \mathrm{~g} / \mathrm{L} \mathrm{MgCl}_{2}, 0.75 \mathrm{~g} / \mathrm{L} \mathrm{KCl}\right.$, $30 \mathrm{~g} / \mathrm{L} \mathrm{NaCl}$ ) solutions. The mixture of residue and complex salt solution was stirred for $2 \mathrm{~h}$ using a magnetic stirrer. Then, it was filtered using Whatman filter paper in order to discard spent solid. The filtrate was poured in a sufficiently agitated beaker and heated at $70{ }^{\circ} \mathrm{C}$ for $2 \mathrm{~min}$ to precipitate out the needed biocoagulant from the filtrate solution. The precipitated biocoagulant (MSC) was poured into the specified filter paper(s) and allowed to dry at room temperature for $24 \mathrm{~h}$ to solid biocoagulant.

\subsection{Coagulation-flocculation procedure}

The coagulation-flocculation experiments were conducted using a jar test apparatus at room temperature and are described as follows.

\subsubsection{Influence of dosage of MSC on removal efficiency}

The initial turbidity was measured using a Digital Turbidimeter (model WZS-185, Japan). The $\mathrm{pH}$ of produced water (PW) was also recorded at room temperature. For each run, $1000 \mathrm{~mL}$ of $\mathrm{PW}$ samples were poured in ten different $1000 \mathrm{~mL}-\mathrm{GG}-17$ beakers. The desired dosages of MSC were between 0.5 and $5 \mathrm{~g} / \mathrm{L}$. The jar testing started when desired MSC dosages were put into PW samples contained in the $1000 \mathrm{~mL}$ beakers and rapid mixed at $250 \mathrm{rpm}$ for $3 \mathrm{~min}$. This was followed by slow agitation at $30 \mathrm{rpm}$ for $40 \mathrm{~min}$. After slow mixing, the treated PW samples were immediately transferred into $1000 \mathrm{~mL}$ Borex measuring cylinders. Then, each of the PW samples in the various cylinders was allowed to settle for $35 \mathrm{~min}$. During the settling time, $15 \mathrm{~mL}$ of the supernatant (upper layer of the settling effluent) was pipetted from $3 \mathrm{~cm}$ depth into a $120 \mathrm{~mL}$ cuvette. Residual particle concentrations of supernatants were recorded. The residual particle concentration (in $\mathrm{mg} / \mathrm{L}$ ) was obtained as a product of residual turbidity (NTU) and conversion factor $\left(T_{\mathrm{f}}\right) . T_{\mathrm{f}}$ has a value of 2.35 (Metcalf and Eddy Inc 2003).

\subsubsection{Influence of $\mathrm{PW} p \mathrm{pH}$ on removal efficiency}

For the evaluation of the effect of $\mathrm{pH}$, the optimum dosage of MSC obtained in Sect. 2.2.1 was used in the jar test as described below: the $\mathrm{pH}$ of $\mathrm{PW}$ was adjusted to desired $\mathrm{pH}$ using $0.1 \mathrm{M} \mathrm{H}_{2} \mathrm{SO}_{4}$ and $0.1 \mathrm{M} \mathrm{NaOH}$ just before dosing of the MSC. After the adjustment, MSC samples with optimum dosage were separately put into eight beakers containing $1000 \mathrm{~mL} \mathrm{PW}$, and subsequently rapid mixed $(250 \mathrm{rpm})$ for $3 \mathrm{~min}$ and slow mixed $(30 \mathrm{rpm})$ for $40 \mathrm{~min}$ using a magnetic stirrer. After the slow mixing, each of the treated PW sample was allowed to settle for $30 \mathrm{~min}$. During settling time, $15 \mathrm{~mL}$ of the supernatant was withdrawn from $3 \mathrm{~cm}$ depth and measured for particle concentration $(\mathrm{mg} / \mathrm{L})$ at the specified $\mathrm{pH}$.

\subsubsection{Influence of time on removal efficiency}

First, an optimum amount of MSC was put into a beaker containing $1000 \mathrm{~mL} \mathrm{PW}$. Then, the mixture of PW and MSC was rapid mixed at $250 \mathrm{rpm}$ for $3 \mathrm{~min}$, and then slow mixed at $30 \mathrm{rpm}$ for $40 \mathrm{~min}$, using a magnetic stirrer. Finally the treated PW was allowed to settle for $30 \mathrm{~min}$. During settling period, the particle concentrations were determined at $3,5,10,15,20,25$, and 30 min using conversion factor of 2.35 .

\subsection{Instrumental characterization}

The precursor (MS), biocoagulant (MSC), and settled sludge (PTSS) were characterized using the following instruments: (i) Thermo Nicolet Nexus 470/670/870FTIR unit (Thermo Nicolet Corporation, USA), (ii) Zeiss $\mathrm{EVO}^{\circledR} \mathrm{MA} 15$ EDX/WDS unit (Zeiss, USA) (surface morphology), (iii) PHILIPS X PERT X-RAY diffraction unit (PANalytical, USA) with $\mathrm{Cu} \mathrm{Kr}$ radiation $(30 \mathrm{kV}$ and $30 \mathrm{~mA}$ ) at a scan rate of $1 \% \mathrm{~min}$ (XRD), (iv) TGA-Q50 and DSC-Q200 unit (TA Instruments, USA) (Thermal stability).

\section{Kinetics theory and model development for coagulation process}

\subsection{The Brownian coagulation theory}

In an aqueous suspension, where Brownian motion dominates, the number of collision occurring per unit time per unit volume, $K_{x y}$, for two particles of volumes $V_{x}$ and $V_{y}$ is expressed as (von Smoluchowski 1917; Liyang 1988; Holthof et al. 1996; Menkiti et al. 2010):

$K_{x y}=\beta_{\mathrm{BR}}\left(v_{x} v_{y}\right) n_{x} n_{y}$

where $\beta_{\mathrm{BR}}\left(v_{x} v_{y}\right)$ is the Brownian aggregation collision frequency which depends on particle size, temperature, and pressure; $n_{x} n_{y}$ is the particle concentrations for two particles of sizes $x$ and $y$. 
The formation rate $r_{\mathrm{f}}$ of particles of volume $v_{p}$, as a result of collisions between particles of volumes $v_{x}$ and $v_{y}$ is expressed as (Liyang 1988; Okolo et al. 2014):

$r_{\mathrm{f}}=\frac{1}{2} \sum_{x+y=p} K_{x y}$

Note that $x+y=p$ shows that the summation is governed by collisions, for which

$v_{x}+v_{y}=v_{p}$

In a reverse case, the dissociation rate of particles of volume $v_{p}$ by collision with other particles is given as (Liyang 1988; Okolo et al. 2014):

$r_{1}=\sum_{x=1}^{\infty} K_{x k}$

Hence, the rate of change in the number of density of particles of volume $V_{p}$ is

$\frac{\mathrm{d} n_{k}}{\mathrm{~d} t}=r_{\mathrm{f}}-r_{1}$,

Substituting Eqs. (2) and (4) into Eq. (5), yields

$\frac{\mathrm{d} n_{k}}{\mathrm{~d} t}=\frac{1}{2} \sum_{x+y} \beta_{\mathrm{BR}}\left(V_{x} V_{y}\right) n_{x} n_{y}-n_{k} \sum_{x=1}^{\infty} \beta_{\mathrm{BR}}\left(V_{x} V_{p}\right) n_{x}$

The collision frequency function can be obtained through the steady-state particle diffusion as:

$k_{x y}=4 \pi\left(D_{x}+D_{y}\right)\left(a_{x}+a_{y}\right)$,

where $D_{x}+D_{y}=D_{p}$.

Thus Eq. (7) is simplified to:

$k_{x y}=4 \pi\left(D_{p}\right)\left(a_{x}+a_{y}\right)$

For a monodisperse system where particles of volume, $v_{x}=v_{y}$, the Einstein-Stokes relation could be expressed as Eq. (9) (Holthof et al. 1996):

$D_{x}=\frac{K T}{6 \pi \mu a_{x}}$ and $D_{y}=\frac{K T}{6 \pi \mu a_{y}}$

Hence the Einstein-Stokes equation is reduced to:

$D_{x}=\frac{K T}{6 \pi \mu}\left(\frac{1}{a_{x}}+\frac{1}{a_{y}}\right)$

Inserting Eq. (10) into Eq. (8) yields:

$$
\begin{aligned}
K_{x y} & =4 \pi\left(\frac{K T}{6 \pi \mu}\left(\frac{1}{a_{x}}+\frac{1}{a_{y}}\right)\left(a_{x}+a_{y}\right)\right) \\
K_{x y} & =\frac{2}{3} \frac{K T}{\mu} \frac{\left(a_{x}+a_{y}\right)^{2}}{a_{x}+a_{y}}
\end{aligned}
$$

For the collision frequency function of Eq. (12), for the case of monodisperse dimer formation, the following conditions apply: $\frac{\left(a_{x}+a_{y}\right)^{2}}{a_{x} a_{y}}=\left(\begin{array}{cc}4 & \text { for } a_{x}=a_{y} \\ >4 & \text { for } a_{x} \neq a_{y}\end{array}\right)$

and for the case of $a_{x}=a_{y}$, Eq. (12) transforms to Eq. (13):

$K_{11}=\frac{8 K T}{3 \mu}$,

where $K_{11}$ is the Von Smoluchowski coagulation rate constant.

Also for the case of $K_{x y} \rightarrow K_{11}=\beta_{\mathrm{BR}}\left(v_{x} v_{y}\right) n_{x} n_{y}$, Eq. (6) is solved exactly to yield:

$\frac{N_{t}}{N_{0}}=\frac{\left(K_{11} N_{0} t / 2\right)^{n-1}}{\left(1+K_{11} N_{0} t / 2\right)^{n+1}}$

It has been established for an aggregating system at $n=1$; it could be extended into flocculation regime, such that

$K_{11} \approx K_{m}$ (Menkiti and Onukwuli 2012), and Eq. (14) transforms to Eq. (15):

$\frac{1}{\sqrt{N_{L}}}=\left(\frac{K_{m} N_{0}}{\sqrt[2]{N_{0}}}\right) t+\frac{1}{\sqrt{N_{0}}}$,

where $K_{m}=\frac{1}{2} \beta_{\mathrm{BR}}=\frac{2}{3} \varepsilon_{p} \frac{K_{\mathrm{B}} T}{\eta}$.

$K_{m}$ is the Menkonu coagulation-flocculation rate constant accounting for Brownian coagulation-flocculation transport of destabilized particles at $\alpha$ th order. $\varepsilon_{p}$ is the collision efficiency.

The coagulation-flocculation period is obtained from Eq. (14) as

$t_{1 / 2}=\frac{1}{\left(0.5 K_{m} N_{0}\right)}$

The physical significance of Eq. (16) is that it represents the time at which the initial total number of particles is reduced by half and it is therefore a coagulation time scale.

The coagulation-flocculation efficiency could be calculated using Eq. (17)

$E(\%)=\left(\frac{N_{0}-N_{t}}{N_{0}}\right) \times 100$

\section{Results and discussion}

\subsection{Characterization results}

\subsubsection{Characteristics of produced water $(P W)$}

The characteristics of PW are shown in Table 1. The conductivity value obtained in Table 1 showed that PW contained charged ions from different substances that made 
Table 1 Characteristics of produced water (PW)

\begin{tabular}{lll}
\hline Parameter & Value & Unit \\
\hline $\mathrm{pH}$ & 8 & \\
$\mathrm{Fe}^{2+}$ & 0.711 & $\mathrm{mg} / \mathrm{L}$ \\
$\mathrm{SO}^{2-}$ & 26 & $\mathrm{mg} / \mathrm{L}$ \\
$\mathrm{NO}_{3}{ }^{2-}$ & 12.8 & $\mathrm{mg} / \mathrm{L}$ \\
$\mathrm{Alkalinity}^{2+}$ & 1820.5 & $\mathrm{mg} / \mathrm{L}$ \\
$\mathrm{Acidity}^{2+}$ & 202 & $\mathrm{mg} / \mathrm{L}$ \\
$\mathrm{Ca}^{2+}$ & $\mathrm{Nil}$ & $\mathrm{mg} / \mathrm{L}$ \\
$\mathrm{Mg}^{2+}$ & $\mathrm{Nil}$ & $\mathrm{mg} / \mathrm{L}$ \\
$\mathrm{Salinity}^{+}$ & 3842 & $\mathrm{mg} / \mathrm{L}$ \\
Turbidity & 1435 & $\mathrm{NTU}$ \\
Conductivity & 12.17 & $\mathrm{~ms} / \mathrm{mc}$ \\
Total dissolved solids & 1899 & $\mathrm{mg} / \mathrm{L}$ \\
Total suspended solids & 1473 & $\mathrm{mg} / \mathrm{L}$ \\
COD & 10 & $\mathrm{mg} / \mathrm{L}$ \\
Hydrocarbon & 99.7 & $\mathrm{ppm}$ \\
\hline
\end{tabular}

Table 2 Proximate analysis results of mucuna seed

\begin{tabular}{lcc}
\hline Parameter & Value & Unit \\
\hline Bulk density & 0.53 & $\mathrm{~g} / \mathrm{mol}$ \\
Oil content & 5.30 & $\%$ \\
Ash content & 2.80 & $\%$ \\
Moisture content & 11.0 & $\%$ \\
Protein content & 22.7 & $\%$ \\
Weight loss & 10.9 & $\%$ \\
Yield & 89.0 & $\%$ \\
\hline
\end{tabular}

up the PW. The high turbidity of PW in Table 1 was due to the suspended solids which accounted for the cloudiness of the effluent. The values as represented in Table 1 were adequate to favor coagulation-flocculation treatment of PW.

\subsubsection{Mucuna seed (MS)}

Shown in Table 2 are the physiochemical parameters values of MS, such as yield (\%), weight (\%), bulk density ( $\mathrm{g} /$ $\mathrm{mL}$ ), ash content $(\%)$, oil content $(\%)$, moisture content $(\%)$, and protein content $(\%)$, which were obtained based on the standard AOAC methods (Atkins 1990). The calculated yield value depicted in Table 2 is significant to highlight the prospect of MS as a good precursor that could be processed into MSC.

\subsubsection{FTIR spectra analyses of MS, MSC, and PTSS}

The prevalent functional groups of MS, MSC, and PTSS were determined from Fig. 1 using spectra $\left(4000-600 \mathrm{~cm}^{-1}\right)$ that were compared to an FTIR library (Stuart 2004). Figure 1 shows the peaks of $3700-3500 \mathrm{~cm}^{-1}$ for: (a) MS, (b) MSC, and (c) PTSS, and were attributed to $\mathrm{O}-\mathrm{H}$ groups. The peaks in the range of $3288-3335 \mathrm{~cm}^{-1}$ were attributed to secondary amide. An aliphatic ring was linked to the region of 2918-2850 $\mathrm{cm}^{-1}$ for (a) MS $\left(2919 \mathrm{~cm}^{-1}\right)$, (b) MSC $\left(2918-2850 \mathrm{~cm}^{-1}\right)$, and (c) PTSS $\left(2919-2850 \mathrm{~cm}^{-1}\right)$. The medium peaks range $\left(1720-1528 \mathrm{~cm}^{-1}\right)$ are recorded for MSC $\left(1623,1558-1541 \mathrm{~cm}^{-1}\right.$ for $\left.\mathrm{NH}_{2}\right)$ and PTSS (1558-1539 $\mathrm{cm}^{-1}$ for $\mathrm{N}-\mathrm{H}$ bending; $\mathrm{C}-\mathrm{N}$ stretching and $\mathrm{NO}_{2}$ asymmetric). Peaks at 1362,1298 , and $1284 \mathrm{~cm}^{-1}$ were assigned to MS with $\mathrm{SO}_{2}$ asymmetric stretching. Also, $\mathrm{S}=\mathrm{O}$ stretching $\left(1206 \mathrm{~cm}^{-1}\right)$, B-H bending $\left(1020 \mathrm{~cm}^{-1}\right)$, and out of plane $\mathrm{C}-\mathrm{H}$ bending $\left(944-609 \mathrm{~cm}^{-1}\right)$ were for MS. Peaks at 1456,1417 , and $1488 \mathrm{~cm}^{-1}$ denoted azo compound $(\mathrm{N}=\mathrm{N}$ stretching) in MSC and PTSS. Bands for MSC at $897-945 \mathrm{~cm}^{-1}$ and PTSS at $712-699 \mathrm{~cm}^{-1}$ were attributed to $\mathrm{C}-\mathrm{H}$ stretching.

\subsubsection{SEM/elemental results of MS, MSC, and PTSS}

Figures 2, 3, and 4 show the surface morphologies of MS, MSC, and PTSS. Two images $(a, b)$, were obtained at different magnifications for each of Figs. 2, 3, and 4. Figure 2a for MS depicts the aggregated porous network structure of tender looking tissue. Figure $2 b$ for MS depicts magnified, multiple aggregated networked pores that are evenly distributed. These pores are an initial indication of active sites for sticking of particles. Figure 3a for MSC shows more enlarged pores in the MSC. The multiple predominant pores characterized by rounded protrusions indicated added porosity after processing MS into MSC. Figure 4 for PTSS shows a highly compact and filled structure without voids. The filled pores indicated that the particles readily attached on the surfaces of the pores to form the sludge. The existence of the white region could be as a result of transfer of potassium-based compounds from effluent to MSC to form PTSS. Table 3 shows the elemental compositions of MS, MSC, and PTSS. Clearly the presence of elements, originally not seen in MSC, but subsequently present within PTSS matrix, was an indication of transfer of elements/particles from PW to the MSC.

\subsubsection{XRD result of MS, MSC, and PTSS}

The X-Ray diffraction for: (a) MS, (b) MSC, and (c) PTSS are depicted in Fig. 5. Figure 5a reveals the presence of broad peaks, indicating the poor crystalline nature of the MS sample. Figure $5 \mathrm{~b}$, for MSC shows five clear peaks while Fig. 5c for PTSS shows 12 clear peaks. The crystal peaks in Figs. 5b, c on comparison with the standard crystal peaks were shifted towards left-right axes, which 
Pet. Sci. (2016) 13:328-339

333
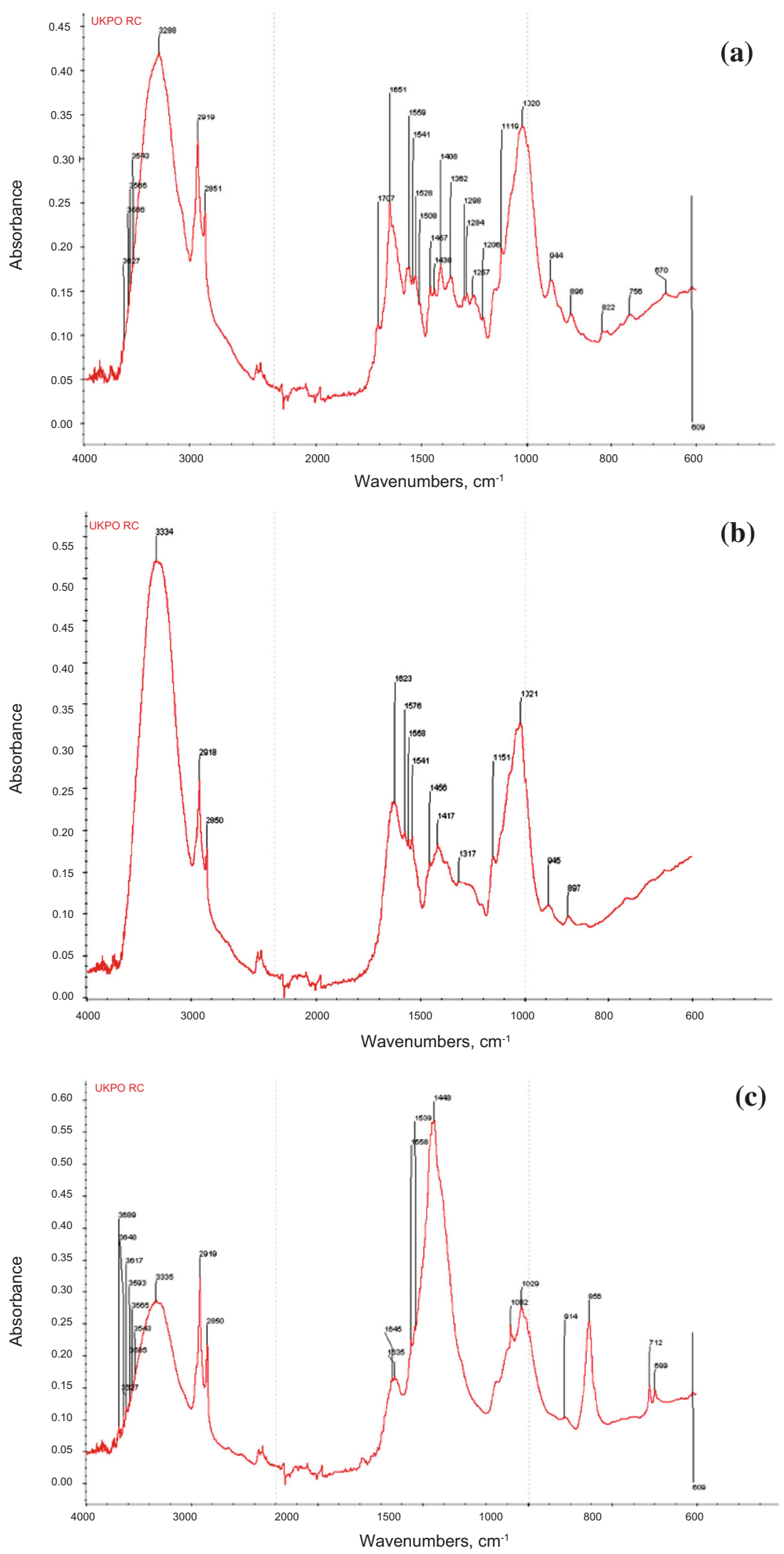

Fig. 1 FTIR spectra for a MS, b MSC, c PTSS

Springer 


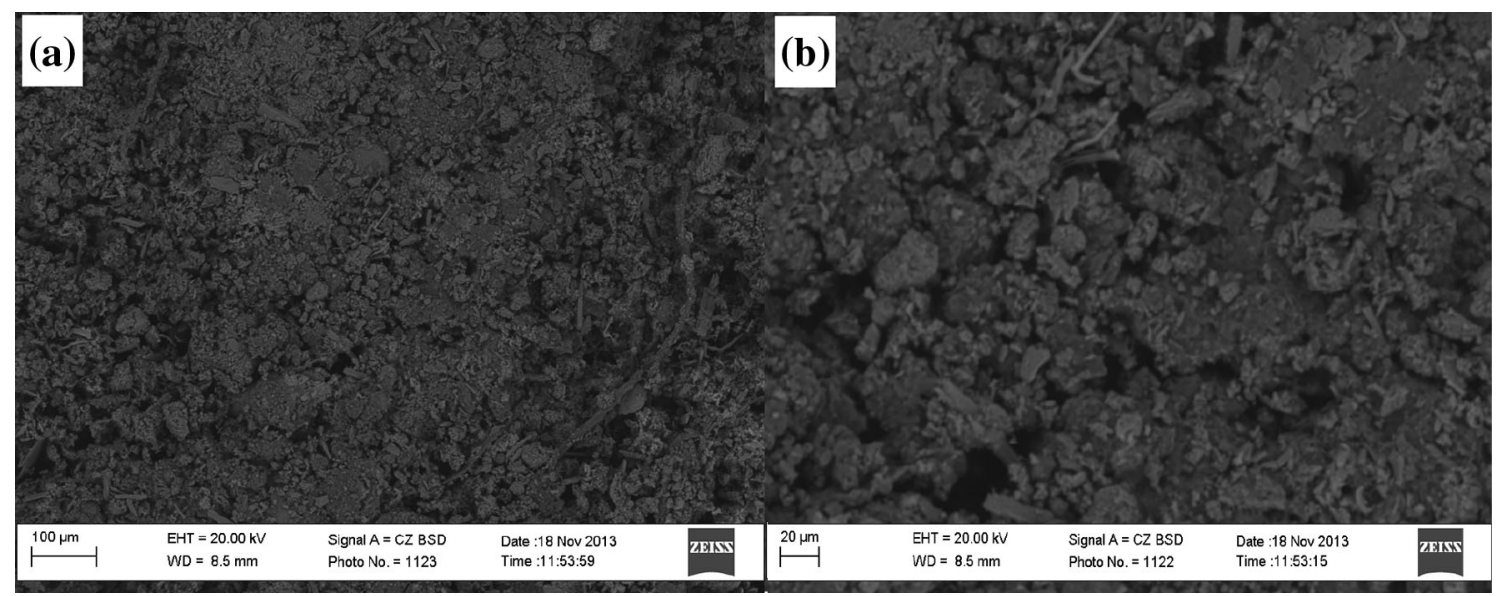

Fig. 2 SEM micrographs of MS

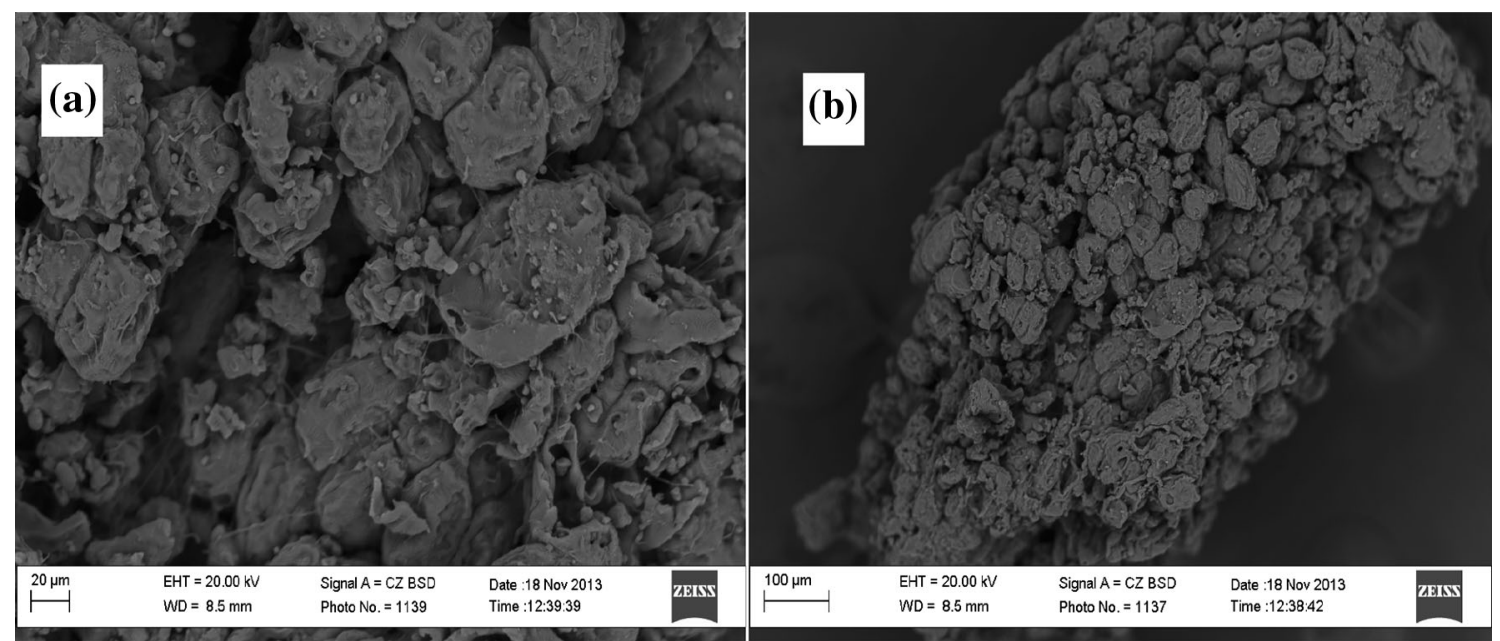

Fig. 3 SEM micrographs of MSC

might be the result of expansion or contraction of MSC (Ezemagu 2015). Figure 5b, c indicated primitive lattice structure for MSC and PTSS, respectively. MS was poorly crystalline.

\subsubsection{TGA/DSC of mucuna seed (MS), mucuna seed coagulant (MSC), and post treated settled sludge (PTSS)}

These are analyses (TGA and DSC) that account for the thermal behavior of samples (Brukh and Mitra 2007; Vyazovkin 2012; Menkiti et al. 2014). Figures 6, 7, and 8 show the TGA and DSC curves for MS, MSC, and PTSS. The thermograms shown in Fig. 6a (MS) and Fig. 7a (MSC) had final residual mass of $1.189 \mathrm{mg}$ (27.5\% original mass) and $1.839 \mathrm{mg}$ (60\% original mass), respectively. In Figs. 6a and 7a, the first weight losses resulted from internal moisture and gaseous losses from the samples
(Menkiti et al. 2014). Furthermore, weight losses were linked to the decomposition of the labile component in both MS and MSC.

Phase transition occurred over the temperature ranges of 37.5-298 and $25-298^{\circ} \mathrm{C}$, with transition enthalpies of 13.779 and $11.8421 \mathrm{~kJ} / \mathrm{mol}$ (Figs. 6b, 7b), respectively. Both Figs. $6 \mathrm{~b}$ and $7 \mathrm{~b}$ demonstrated the coiling of the long chain protein moiety, leading to spontaneous densification. At $125-298$ and $162.5-298.5^{\circ} \mathrm{C}$, the densification occurred with absorption of thermal energy (Figs. 6b, 7b). This was an indication that the heat flow disks exhibited exothermicity.

Figure 8 shows the TGA/DSC of PTSS. Figure $8 \mathrm{a}$ for PTSS shows dehydration and volatilization that persisted till $262.5{ }^{\circ} \mathrm{C}$, losing about $10 \%(0.352 \mathrm{mg})$ of its weight (Verma et al. 2010; Ezemagu 2015). Between 262.5-450 ${ }^{\circ} \mathrm{C}$, the residue oxidized and lost about $15 \%$ $(0.88 \mathrm{mg})$ of its weight. At maximum $590{ }^{\circ} \mathrm{C}$ in Fig. $8 \mathrm{a}$, 


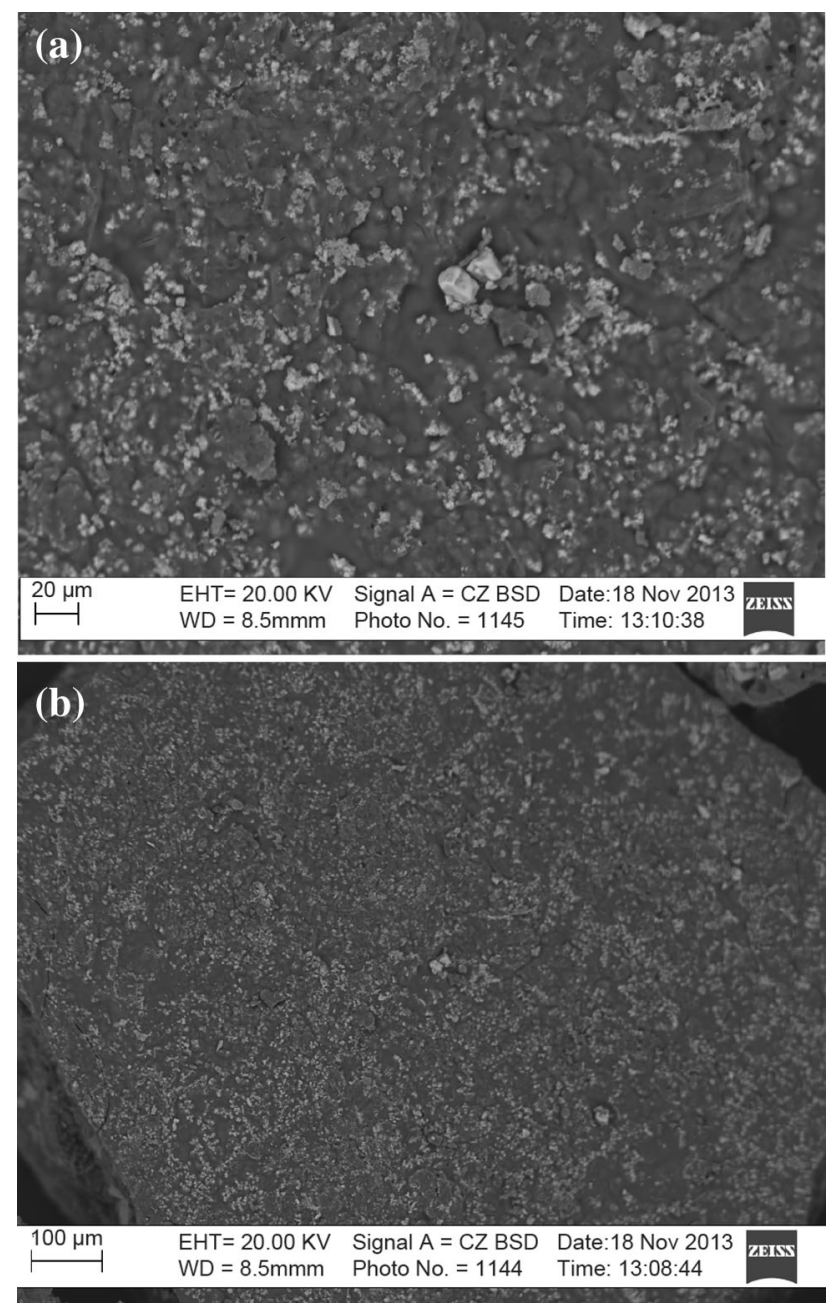

Fig. 4 SEM micrographs of PTSS

Table 3 Elemental composition of MS, MSC, and PTSS

\begin{tabular}{llll}
\hline Element, wt $\%$ & MS & MSC & PTSS \\
\hline $\mathrm{C}$ & 9.43 & 16.03 & 11.49 \\
$\mathrm{Na}$ & 8.24 & 2.75 & 18.13 \\
$\mathrm{Mg}$ & 0.19 & 0 & 1.47 \\
$\mathrm{Al}$ & 0 & 3 & 2.42 \\
$\mathrm{Si}$ & 0.2 & 0 & 3.99 \\
$\mathrm{P}$ & 0.43 & 0.57 & 0.52 \\
$\mathrm{~S}$ & 0 & 6 & 1.36 \\
$\mathrm{Cl}$ & 39.14 & 2.3 & 10.97 \\
$\mathrm{~K}$ & 24.17 & 0.43 & 0.6 \\
$\mathrm{Ca}$ & 7.19 & 41.56 & 20.06 \\
$\mathrm{Ti}$ & 0 & 3.73 & 0.19 \\
$\mathrm{Fe}$ & 0 & 0 & 2.95 \\
$\mathrm{Cu}$ & 0 & 0 & 0 \\
$\mathrm{O}$ & 11.01 & 23.63 & 25.85 \\
\hline
\end{tabular}
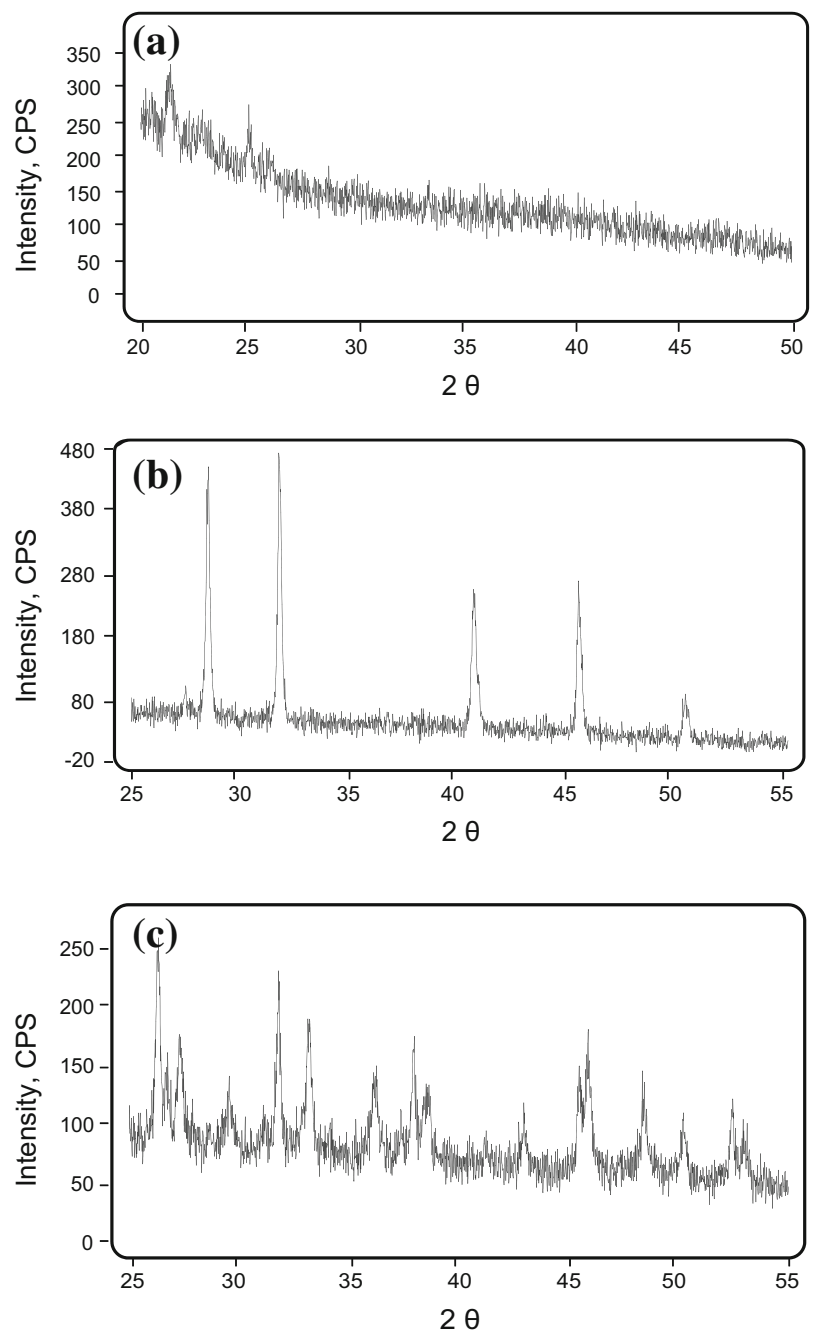

Fig. 5 XRD pattern of: a MS, b MSC, c PTSS

PTSS lost $1.1 \mathrm{mg}$ of its initial mass (3.520 g). At $590{ }^{\circ} \mathrm{C}$, oxidation and dehydration of sample were at maximum (Verma et al. 2010). The weight loss could be attributed to fragmentation or decomposition of labile components in the sample. The interactive effects of MSC with various chemical substances and particles contained in PW are shown as two eutectics downward peaks in Fig. 8b. The presence of the two peaks in Fig. $8 \mathrm{~b}$ indicated that the components of the sample were not a single pure substance. However, Figs. 6, 7, and 8 indicated thermal stability.

\subsection{Process factors influence}

\subsubsection{Effect of MSC dosage on particle removal efficiency}

Figure 9 showed that the particle removal efficiency increased from $58.1 \%$ at $0.5 \mathrm{~g} / \mathrm{L}$ of $\mathrm{MSC}$, reaching a maximum of $60 \%$ (at $1 \mathrm{~g} / \mathrm{L}$ of $\mathrm{MSC}$ ) and thereafter 

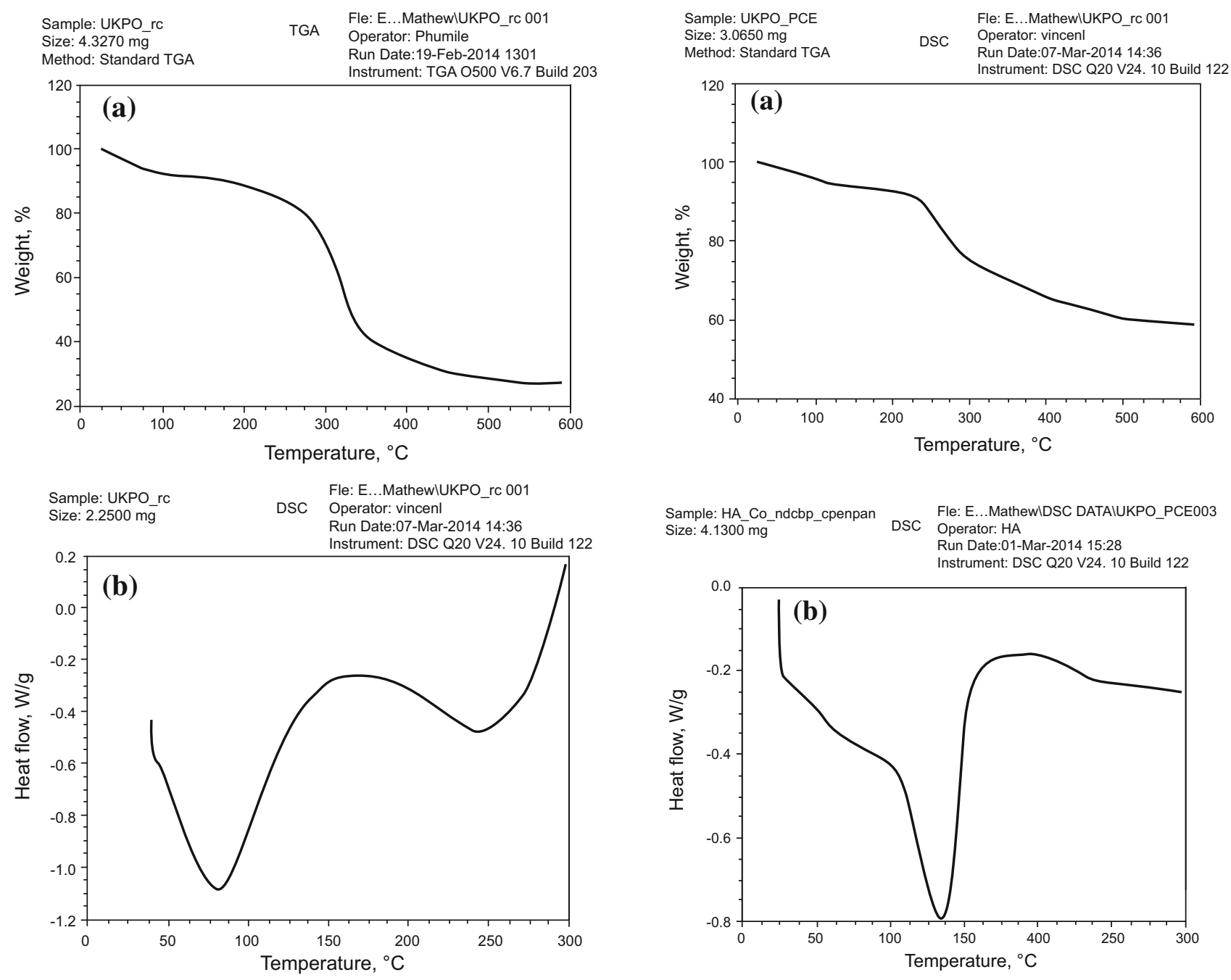

Fig. 6 Profile of a TGA and b DSC of MS

reduced to $52.9 \%$ at $2.5 \mathrm{~g} / \mathrm{L}$. Minimum efficiency was recorded at $50.1 \%$ for $5 \mathrm{~g} / \mathrm{L}$. The removal efficiency increase resulted from increased protonation of the fluid, which incrementally destabilized PW-charged species (mainly - ve charges), leading to the particle removal efficiency increasing as MSC dosage increased from 0.5 to $1 \mathrm{~g} / \mathrm{L}$. The removal efficiency then declined with increasing MSC dosage (1.5-5 g/L). The decline resulted from sustained restabilization and returbidization following net protonation of the fluid after $1 \mathrm{~g} / \mathrm{L}$ MSC dosing was exceeded. In this work, $1 \mathrm{~g} / \mathrm{L}$ was adopted as optimal dosage and applied in the evaluation of $\mathrm{pH}$ effect in Sect. 4.2.2.

\subsubsection{Effect of $\mathrm{pH}$ on particle removal at $1 \mathrm{~g} / \mathrm{L}$ of $\mathrm{MSC}$}

Figure 10 shows the effect of $\mathrm{pH}$, varied from $2-9$, on particle removal. The profile in Fig. 10 indicated alternate decline and increment in performance as the $\mathrm{pH}$ changed

Fig. 7 Profile of a TGA and b DSC of MSC

from 9-2. The particle removal efficiency which rose in $\mathrm{pH}$ ranges of 3-2 and 7-5 could be linked to increased protonation of the fluid. Conversely, the declined in performance at $\mathrm{pH}$ ranges 9-7 and 5-3 could be linked to +ve and -ve species-induced charge reversal, respectively. The charge reversal occurred when either one of the charged species was in excess. The maximum removal efficiency of $84 \%$ at $\mathrm{pH} 2$ indicated a point of equilibrium in the concentrations of ions and counter-ions participating in the coagulation-flocculation process (Menkiti and Onukwuli 2012).

\subsubsection{Variation of particle removal efficiency with time at $1 \mathrm{~g} / \mathrm{L}$ of $\mathrm{MSC}$ and $\mathrm{pH} 2$}

The variation of particle removal efficiency with time at $1 \mathrm{~g} / \mathrm{L}$ of MSC and $\mathrm{pH} 2$ is shown in Fig. 11. Figure 11 shows that the particle removal efficiency gradually 

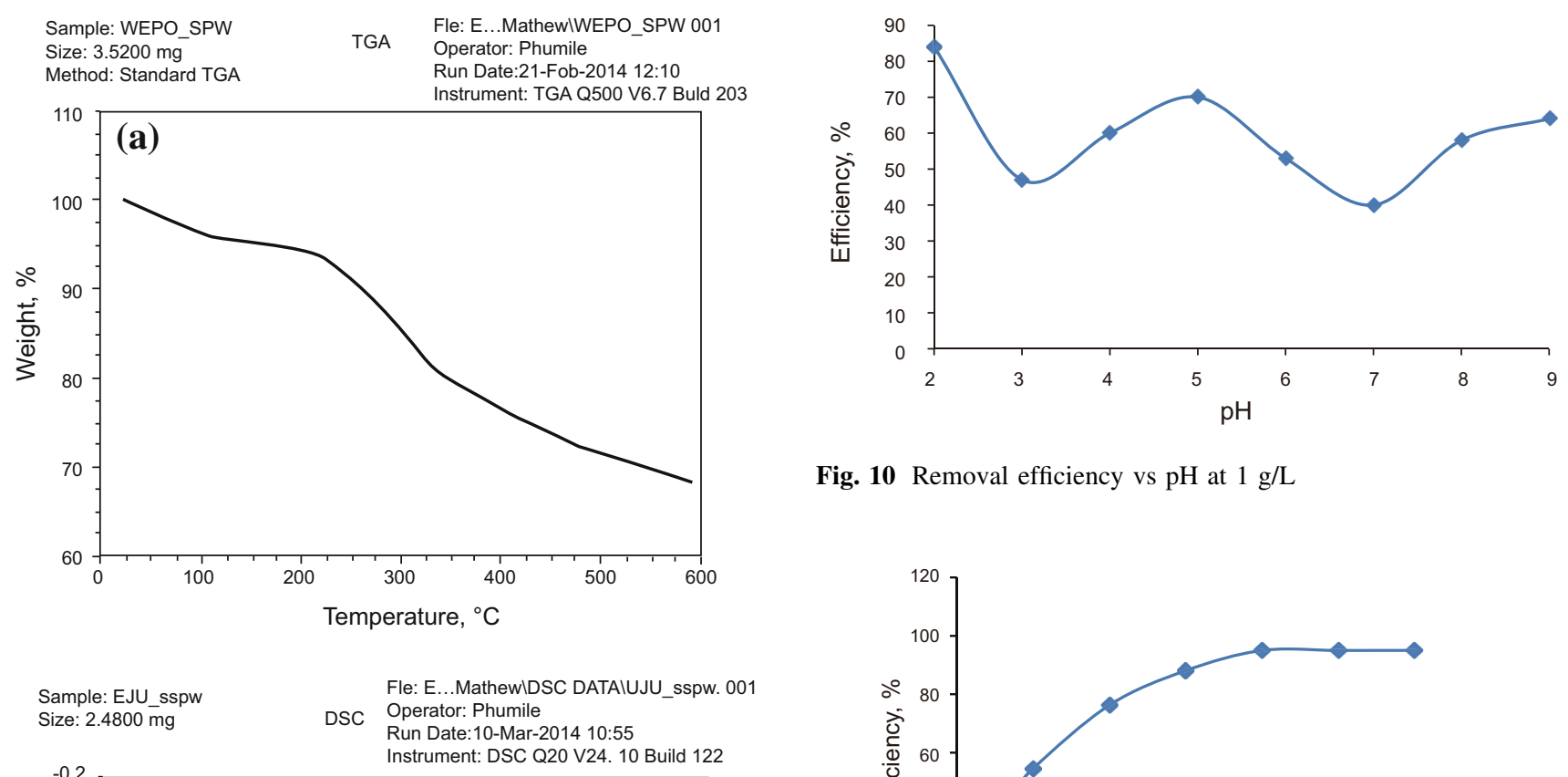

Fig. 10 Removal efficiency vs $\mathrm{pH}$ at $1 \mathrm{~g} / \mathrm{L}$

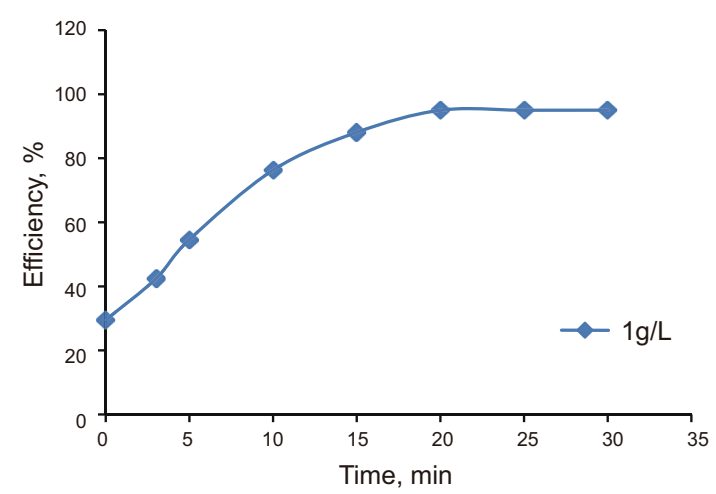

Fig. 11 Influence of time on efficiency at $1 \mathrm{~g} / \mathrm{L}$ and $\mathrm{pH} 2$

Table 4 Nephelometric kinetics parameters

\begin{tabular}{ll}
\hline Parameter & Value \\
\hline$K_{m}, \mathrm{~L} / \mathrm{g} / \mathrm{s}$ & 0.0001 \\
$\frac{1}{N_{0}}, \mathrm{~L} / \mathrm{g}$ & 0.0015 \\
$N_{0}, \mathrm{~g} / \mathrm{L}$ & 666.6 \\
$R^{2}$ & 0.989 \\
$\tau^{1 / 2}, \mathrm{~s}$ & 30.003 \\
$K_{R}, \mathrm{~g}^{2} / \mathrm{s}$ & $3.00 \mathrm{E}-10$ \\
$\beta_{\mathrm{BR}}, \mathrm{L} / \mathrm{g} / \mathrm{s}$ & 0.0002 \\
$-r$ & $6.00 \mathrm{E}-07$ \\
$D^{\prime}, \mathrm{g}^{2} / \mathrm{m} / \mathrm{s}$ & $2.00 \mathrm{E}-05$ \\
$\alpha$ & 2 \\
\hline
\end{tabular}

\subsection{Process kinetics}

Table 4 displays nephelometric kinetics results evaluated at $\mathrm{pH} 2,1 \mathrm{~g} / \mathrm{L}$ of MSC, and an initial particle load of $3372 \mathrm{~g} / \mathrm{L}$. The overall rate constant $K_{m}$ was obtained as a slope of the plot (plot not shown) of $\frac{1}{\sqrt{N_{t}}}$ vs $t$ (Eq. 15), for the case of $\alpha=2 . K_{m}$ is a vital parameter that indicates the speed of floc formation and it accounted for the aggregation process that started from initial coagulation to viable floc formation and subsequent settling. The higher the 
value of $K_{m}$, the higher the efficiency in clarification. Preferentially, best results can be obtained at $\alpha$ range of 1-2 (Menkiti and Onukwuli 2012; Ugonabo et al. 2012). For the process kinetics, the value of $R^{2}$ indicates a second-order model for the perikinetic process. For perikinetics, $2 K_{m}=$ $\beta_{\mathrm{BR}}$. A high magnitude $K_{m}$ translates to high kinetic energy necessary to reduce the zeta potential within the fluid medium. The result would be substantial reduction in double layer effects or improved colloidal destabilization at low $\tau_{1 / 2}$ (30.003 s) to enhance the high rate of process aggregation.

\section{Conclusion}

In this report, the performance of MS extract as an effective biocoagulant has been established at the conditions of this study. The process effectively removed $84 \%$ of particle load from the PW effluent. Also, the study showed that dosage and $\mathrm{pH}$ had significant influence on the performance of MSC. Characteristics of MSC have shown biomass with sufficient active surface to be used as a biocoagulant. The sample would be also considered thermally stable. The sludge composition indicates it could be a resource for materials absorbed from the effluents.

Open Access This article is distributed under the terms of the Creative Commons Attribution 4.0 International License (http://crea tivecommons.org/licenses/by/4.0/), which permits unrestricted use, distribution, and reproduction in any medium, provided you give appropriate credit to the original author(s) and the source, provide a link to the Creative Commons license, and indicate if changes were made.

\section{References}

Amokrane A, Comel C, Veron J. Landfill leachates pre-treatment by coagulation-flocculation. Water Res. 1997;31:2775-82.

APHA (American Public Health Association), AWWA (American Water Works Association), WPCF (Water Pollution Control Federation). Standard methods for the examination of water and wastewater. Washington, DC: APHA; 1999.

Atkins PW. Physical chemistry. 4th ed. Oxford: Oxford University Press; 1990.

Bouaziz M, Gargouri B, Gargouri OD, et al. Application of electrochemical technology for removing petroleum hydrocarbons from produced water using lead dioxide and boron-doped diamond electrodes. Chemosphere. 2014;117:309-15.

Brukh R, Mitra S. Kinetics of carbon nanotube oxidation. J Mater Chem. 2007;17:619-23.

Chen T, Gao B, Yue Q. Effect of dosing method and $\mathrm{pH}$ on color removal performance and floc aggregation of polyferric chloridepolyamine dual-coagulant in synthetic dyeing wastewater treatment. Colloids Surf A. 2010;355:121-9.

Choi KJ, Kim SG, Kim SH. Removal of antibiotics by coagulation and granular activated carbon filtration. J Hazard Mater. 2008; $151: 38-43$

Colberg JS, Wang X, Goual L. Characterization and treatment of dissolved organic matter from oilfield produced water. J Hazard Mater. 2012;217-218:164-70.
De Godos I, Guzman HO, Soto R, et al. Coagulation/flocculationbased removal of algal-bacterial biomass from piggery wastewater treatment. Bioresour Technol. 2011;102:923-7.

Ezechi EH, Isa MH. Boron removal from produced water using electrocoagulation. Proc Saf Environ Prot. 2014;92:509-14.

Ezemagu IG. Nephlometric study of adsorptive and non-adsorptive component of coagulation of produced water and paint effluent using bioextract. M.Sc. Thesis, Nnamdi Azikiwe University, Awka; 2015.

Frost TK, Johnsen S, Utvik TI. Environmental effects of produced water discharges to the marine environment. OLF, Norway. 1998. http://www.olf.no/static/en/rapporter/producedwater/sum mary.html. Accessed 24 Aug 2015.

Graham N, Gang F, Fowler J, Watts M. Characterization and coagulation performance of a tannin-based cationic polymer: a preliminary assessment. Colloids Surf A. 2008;327:9-16.

Holthof H, Egelhaaf SU, Brorkovee M, et al. Coagulation rate measurement of colloidal particles by simultaneous static and dynamic light scattering. Langmuir. 1996;12:5541.

Huang C, Chen Y. Coagulation of colloidal particles in water by chitosan. J Chem Technol Biotechnol. 1996;66:227-32.

Huang X, Bo X, Zhao Y, et al. Effects of compound bioflocculant on cogulation performance and floc properties for dye removal. Bioresour Technol. 2014;165:116-21.

Imran Q, Hanif MA, Riaz MS, et al. Coagulation/flocculation of tannery wastewater using immobilizedchemical coagulants. J Appl Res Technol. 2012;10(2):79-86.

Jerry N, Kenneth L, Elisabeth MD. Produced water: overview of composition, fates and effects. Environmental risks and advances in mitigation technologies. New York: Springer; 2011. p. 3-54.

Jin Y. Use of a high resolution photographic technique for studying coagulation/flocculation in water treatment. M.Sc. Thesis, University of Saskatchewan, Saskatoon; 2005. p. 22-29.

Karthik M, Dafale N, Pathe P, Nandy T. Biodegradability enhancement of purified terephthalic acid wastewater by coagulation-flocculation process as pretreatment. J Hazard Mater. 2008;154:721-30.

Liyang L. Effect of surface chemistry on kinetics of coagulation of submicron iron oxide particles in water. Pasedena: W.M Keck Laboratory of Environmental Engineering Science, Division of Engineering and Applied Science, California Institute of Technology; 1988. p. 8-10.

Mei Fong C, Chai SL, John R, et al. A review on development and application of plant based biofluocculants and grafted bioflocculants. Ind Eng Chem Res. 2014;53:18357-69.

Menkiti MC, Nnaji PC, Onukwuli OD. Coag-flocculation kinetics and functional parameters response of periwinkle shell coagulant (PSC) to $\mathrm{pH}$ variation in organic rich coal effluent medium. Nat Sci. 2009;7(6):1-18.

Menkiti MC, Nnaji PC, Nwonye CI, et al. Coag-flocculation kinetics and functional parameters response of mucuna seed coagulant to $\mathrm{pH}$ variation in organic rich coal effluent medium. J Miner Mater Charact Eng. 2010;2(8):89-103.

Menkiti MC, Aneke MC, Ejikeme PM, et al. Adsorptive treatment of brewery effluent using activated Chrysophyllum albidium seed shell carbon. SpringerPlus. 2014;3:213.

Menkiti MC, Onukwuli OD. Coag-flocculation of mucuna seed coagflocculant (MSC) in coal washery effluent (CWE) using light scattering effects. AIChE J. 2012;8(4):1303-7.

Metcalf and Eddy, Inc. Waste water engineering: treatment and reuse. 4th ed. New York: Tata-McGraw Hill; 2003.

Moraes LCK. Estudo da. Coagulação-Ultrafiltração com o Biopolímero Quitosana para a Produção de Água Potável. Dissertação de Mestrado. Programa de Pós-Graduação em Engenharia Química, Universidade Estadual de Maringá; 2004.

Okolo BI, Menkiti MC, Nnaji PC, et al. The Performance of okra seed (Hibiscus esculentus L.) extract in removal of suspended 
particles from brewery effluent by coag-flocculation process. $\mathrm{Br}$ J Appl Sci Technol. 2014;4(34):4791-806.

Oluwalana SA, Bolaji W, Martus GD, Alegbeleye O. Domestic water purification using Moringa oleifera. Niger J For. 2004; 29(1):28-32.

Raghuwanshi PK, Meindloi MJ, Sharma AD, et al. Improving filtration quality using agrobased materials as coagulation aid. Water Qual Res Can. 2002;37(4):745-56.

Rajab AH, Idrisa A, Abdullaha N, et al. Production and characterization of a bioflocculant produced by Aspergillus flavus. Bioresour Technol. 2013;127:489-93.

Sciban M, Klasnja M, Anmtov M, et al. Removal of water turbidity by natural coagulants obtained from chestnut and acorn. Bioresour Technol. 2009;100(24):6639-43.

Sen AK, Bulusu KR. Effectiveness of Nirmali seed as coagulant and coagulant aid. Indian J Environ Health. 1962;4:233-44.

Shubo D, Renbi B, Chen JP, et al. Produced water from polymer flooding process in crude oil extraction: characterization and treatment by a novel crossflow oil-water separator. Sep Sci Technol. 2002;29:207-16.

Stuart BH. Infrared spectroscopy: fundamentals and application. Hoboken: Wiley; 2004. p. 71-93.

Sutherland JP. Process for preparing coagulants for water treatment. US Patent, 6,890,565, 10 May 2005.

Tatsi AA, Zouboulis AI, Matis KA, et al. Coagulation-flocculation pretreatment of sanitary landfill leachates. Chemosphere. 2003;53(7):737-44.

Tripathi PN, Chaudhari M, Bokil SD. Nirmali seed-a naturally occurring coagulant. Indian J Environ Health. 1976;18:272-81.

Ugonabo VI, Menkiti MC, Onukwuli OD. Effect of coag-flocculation kinetics on telfairia occidentalis seed coagulant (TOC) in pharmaceutical wastewater. Int $\mathrm{J}$ Multidiscip Sci Eng. 2012;9:22-33.
Ugurlu M, Gurses A, Doğar M, et al. The removal of lignin and phenol from paper mill effluents by electrocoagulation. J Environ Manag. 2008;87:420-8.

Verma S, Prasad B, Mishra I. Pretreatment of petrochemical wastewater by coagulation and flocculation and the sludge characteristics. J Hazard Mater. 2010;178:1055-64.

von Smoluchowski M. Versuch einer mathematischen Theorie der Koagulationskinetik kolloider Lösungen. Z Phys Chem. 1917; 92:129-68.

Vyazovkin S. Thermogravimetric analysis. Characterization of materials. 2nd ed. New York: Wiley; 2012. p. 1-12.

Wang J, Qu C, Liu S. Progress in the development and application of oil field produced water treatment processes. Appl Mech Mater. 2014;641-642:376-9.

Wei JC, Gao BY, Yue QY, et al. Performance and mechanism of polyferric-quaternary ammonium salt composite flocculants in treating high organic matter and high alkalinity surface water. J Hazard Mater. 2009;165:789-95.

Yang Z, Gao B, Yue Q. Coagulation performance and residual aluminum speciation of $\mathrm{Al}_{2}\left(\mathrm{SO}_{4}\right)_{3}$ and polyaluminum chloride (PAC) in Yellow River water treatment. Chem Eng J. 2010;165:122-32.

Zhao G, Ma F, Wei L, et al. Using rice straw fermentation liquor to produce bioflocculant during an anaerobic dry fermentation process. Bioresour Technol. 2012;113:83-8.

Zheng Z, Zhang H, He PJ, et al. Co-removal of phthalic acid esters with dissolved organic matter from landfill leachate by coagulation and flocculation process. Chemosphere. 2009;75:180-6.

Zhu G, Zheng H, Zhang Z, et al. Characterization and coagulationflocculation behavior of polymeric aluminum ferric sulfate (PAFS). Chem Eng J. 2011;178:50-9. 